\title{
Limited initial impacts of biomass harvesting on composition of wood-inhabiting fungi within residual stumps
}

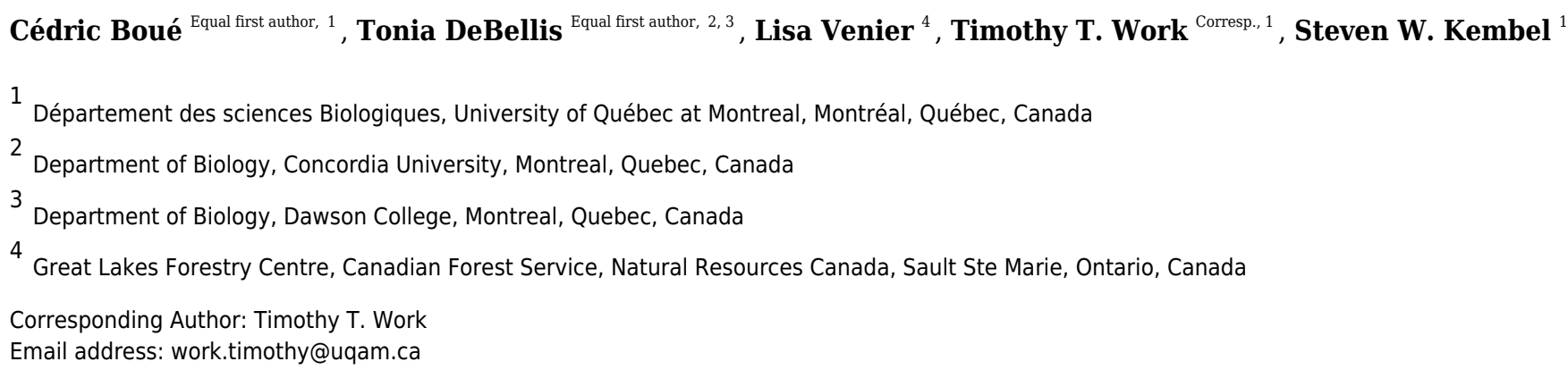

Growing pressures linked to global warming are prompting governments to put policies in place to find alternatives to fossil fuels. In this study, we compared the impact of treelength harvesting to more intensive full-tree harvesting on the composition of fungi residing in residual stumps 5 years after harvest. In the tree-length treatment, a larger amount of residual material was left around the residual stumps in contrast to the full-tree treatment where a large amount of woody debris was removed. We collected sawdust from five randomly selected residual stumps in five blocks in each of the tree-length and full-tree treatments, yielding a total of 50 samples ( 25 in each treatment). We characterized the fungal operational taxonomic units (OTUs) present in each stump using high-throughput DNA sequencing of the fungal ITS region. We observed no differences in Shannon diversity between tree-length and full-tree harvesting. Likewise, we observed few differences in the composition of fungal OTUs among tree-length and full-tree samples using non-metric multidimensional scaling (NMDS). Using the differential abundance analysis implemented with DESeq2, we did, however, detect several associations between specific fungal taxa and the intensity of residual biomass harvest. For example, Peniophorella pallida (Bres.) KH Larss. and Tephromela sp. were found mainly in the fulltree treatment, while Phlebia livida (Pers.) Bres. and Cladophialophora chaetospira (Grove) Crous \& Arzanlou were found mainly in the tree-length treatment. While none of the 20 most abundant species in our study were identified as pathogens we did identify one conifer pathogen species Serpula himantioides (Fr.) P.Karst found mainly in the full-tree treatment. 


\section{Limited initial impacts of biomass harvesting on composition of wood-inhabiting fungi \\ 2 within residual stumps}

5 Cédric Boué $^{+1}$, Tonia De Bellis ${ }^{+2,3}$, Lisa Venier ${ }^{4}$, Timothy T. Work ${ }^{1}$, Steven W. Kembel ${ }^{1}$

$7 \quad$ These authors contributed equally to the manuscript

9 1Département des sciences Biologiques, Université du Québec à Montréal, Montréal, Québec,

10 Canada

$11{ }^{2}$ Department of Biology, Concordia University, Montreal, Quebec, Canada

12 Department of Biology, Dawson College, Montreal, Quebec, Canada

$13{ }^{4}$ Great Lakes Forestry Centre, Canadian Forest Service, Natural Resources Canada, Sault Ste

14 Marie, Ontario, Canada

17 Corresponding Author:

18 Timothy T. Work

19141 Avenue du Président-Kennedy, Montréal, Québec, H2X1Y4, Canada

20 Email: work.timothy@uqam.ca

21

22 


\section{ABSTRACT}

25 Growing pressures linked to global warming are prompting governments to put policies in place to find alternatives to fossil fuels. In this study, we compared the impact of tree-length harvesting to more intensive full-tree harvesting on the composition of fungi residing in residual stumps 5 years after harvest. In the tree-length treatment, a larger amount of residual material was left around the residual stumps in contrast to the full-tree treatment where a large amount of woody debris was removed. We collected sawdust from five randomly selected residual stumps in five blocks in each of the tree-length and full-tree treatments, yielding a total of 50 samples (25 in each treatment). We characterized the fungal operational taxonomic units (OTUs) present in each stump using high-throughput DNA sequencing of the fungal ITS region. We observed no differences in Shannon diversity between tree-length and full-tree harvesting. Likewise, we observed few differences in the composition of fungal OTUs among tree-length and full-tree samples using non-metric multidimensional scaling (NMDS). Using the differential abundance analysis implemented with DESeq2, we did, however, detect several associations between specific fungal taxa and the intensity of residual biomass harvest. For example, Peniophorella

39 pallida (Bres.) KH Larss. and Tephromela sp. were found mainly in the full-tree treatment, while Phlebia livida (Pers.) Bres. and Cladophialophora chaetospira (Grove) Crous \& Arzanlou were

41 found mainly in the tree-length treatment. While none of the 20 most abundant species in our 42 study were identified as pathogens we did identify one conifer pathogen species Serpula 43 himantioides (Fr.) P.Karst found mainly in the full-tree treatment. 
46 Residual forest biomass, including non-merchantable tree-tops and branches, may serve as a

47 renewable feedstock for bioenergy and an alternative to fossil fuels (Mabee and Saddler, 2010;

48 de Jong et al. 2017), and is expected to provide up to $40 \%$ of the world's energy by 2050 (GEA,

49 2012). In regions that have already begun to transition towards increased reliance on bioenergy such as Fennoscandia, the extraction of forest biomass for bioenergy can reduce volumes of

51 residual logging material after harvest by 42-65\% (Rudolphi and Gustafsson 2005; Eräjää et al.

52 2010). However, increased utilization of residual biomass may pose significant conservation

53 risks for many organisms that rely on deadwood either as a habitat or as a resource (Walmsley

54 and Golbold, 2009; Toivanen et al., 2012). Furthermore, because of intensive harvest of timber

55 forest products, numerous fungi are threatened with extinction (Stokland et al., 2012). In

56 Fennoscandian boreal forests, numerous fungal species are dependent on deadwood (Siitonen

57 2001) and more than $40 \%$ of polypore fungi are red listed (Kotiranta et al., 2019).

58 Managed forests contain a lower quantity of deadwood than natural forests (Vallauri et

59 al., 2003; Debeljak 2006; Fridman and Walheim, 2000). For example, Siitonen (2001) has shown

60 that in clear-cut managed boreal forests, the quantity of coarse wood debris $(>10 \mathrm{~cm}$ diameter $)$

61 (i.e. stumps, tree tops, and logs) is less than $10 \%$ of the volume observed in natural forests. Some

62 European forests are currently subject to harvest for biofuel purposes. In these forests, residual

63 biomass will be more intensely harvested than in clear-cut forests. For example, Eräjää et al.

64 (2010) showed that the average residual biomass left on the ground in clear-cut forests is 42.3

$65 \mathrm{~m}^{3}$ ha $\mathrm{a}^{-1}$ while in forest fuel harvesting the quantity of residual biomass remaining is $26.0 \mathrm{~m}^{3} \mathrm{ha}^{-1}$.

66 Numerous studies have shown that intensive residual biomass harvest can reduce species

67 richness and abundance of some non-saproxylic organisms (i.e.: arthropods: spiders, beetles

68 (Work et al., 2014), oribatida (Battigelli et al., 2004); mammals (Sullivan et al., 2011)) and 
69 saproxylic organisms (i.e.: arthropods: beetles: Jonsell, 2008; fungi: Bader et al., 1995;

70 Stockland and Larson 2011).

Residual biomass is an important resource for many organisms and for forest ecosystem

72 function. Coarse woody debris (stumps, logs) is an important habitat and resource in forests for

73 numerous heterotrophic and decomposer organisms (Harmon et al., 1986; de Jong and Dahlberg

74 2017) including beetles (Jonsell et al., 2014), lichens (Svensson et al., 2016), bryophytes (Caruso

75 and Rudolphi, 2009) and wood inhabiting-fungi (Jonsson and Kruys, 2001; Nilsson et al., 2001,

76 Toivanen et al., 2012; Kubart et al., 2016). Futhermore, decomposition of wood by organisms

77 living on coarse woody material including saproxylic fungi (Fukasawa et al., 2009) plays an

78 important role in nutrient cycling and degradation of organic matter (Boddy and Watkinson,

79 1995; Laiho et al., 2004). Although most studies of fungal community composition in forests

80 have focused on coarse woody debris, fine woody debris also appears to be an important habitat

81 for many fungi (Kruys and Jonsson, 1999; Juutilainen et al., 2011; Küffer and al., 2008). For

82 example, Nordén et al. (2004) found that for the same volume of broadleaf tree woody debris,

83 the diversity of Ascomycota is higher in fine woody debris than in coarse woody debris.

84 Decreasing the amount of deadwood and in particular fine woody debris after intensive logging

85 in forest fuel harvesting can also indirectly affect fungi, for example by modifying soil

86 microclimate and influencing fungal networks (Ódor et al., 2006; Brazee et al., 2014). In Norway

87 spruce dead wood, decreasing fungal diversity can lead to reduced rates of decomposition in the

88 early stages (Valentín et al., 2014).

89 Stumps can provide a long-term resource for wood-decaying species compared with

90 smaller diameter woody debris such as branches (De Jong and Dahlberg 2017; Suominen et al.

91 2018), because their rate of decomposition is slower and stumps are often larger and persist 
92 longer in the forest landscape than smaller woody debris (Holeksa et al., 2008). For wood-

93 inhabiting fungi, biomass harvesting may reduce habitat availability and connectivity (Hanski,

94 2005) thus influencing community composition (Nordén et al., 2013) and species occurrence

95 (Hanski 1998). Intensive harvesting of biomass lead to a decrease in the occurrence of fungal

96 fruiting bodies on stumps and wood material $>2 \mathrm{~cm}$ diameter five years after clear-cut harvesting

97 (41\% less in the forest fuel harvesting than clear cut) (Toivanen et al., 2012). In this context,

98 stumps may be one of the only available substrate for fungi after harvesting.

99 Following clear-cutting, the increase of exposure of stump surfaces tends to promote

100 fungal pathogen infestations (Oliva et al., 2010). Some pathogens, such as the basidiomycete

101 Heterobasidium annosum (Fr.) Bref., can spread via mycelia from residual stumps to living tree

102 root systems after harvesting, leading to increased disease and tree mortality. This pathogen also

103 spreads through the air via spores that are deposited most often on tree stumps. Forest pathogen

104 infestations can have major ecological and economic impacts, as for Heterobasidium annosum in

105 the northern hemisphere (Garbelotto and Gonthier, 2013) and is responsible for significant

106 economic losses in Europe (Woodward et al., 1998). Moreover, it has already been demonstrated

107 in Fennoscandinavian forests, that the presence of the pathogen Heterobasidium parviporum

108 Niemelä \& Korhonen on the Norway spruce population can affect forest regeneration (Piri and

109 Korhonen, 2001). For these reasons, it is important to monitor potential infestations caused by

110 pathogens after forest harvesting in order to be able to detect potential economic and ecological

111 losses.

112 In this study we evaluated the response of fungal communities in residual stumps five

113 years post-harvest in two forest harvesting treatments with differing levels of fine and coarse

114 woody debris for use as a biomass feedstock. In the tree-length harvesting treatment, $84 \mathrm{~m}^{3} \mathrm{ha}^{-1}$ 
$115\left(\mathrm{SE}=15 \mathrm{~m}^{3} \mathrm{ha}^{-1}\right)$ of woody material was left behind after cutting, whereas $28 \mathrm{~m}^{3} \mathrm{ha}^{-1}(\mathrm{SE}=3$

$116 \mathrm{~m}^{3} \mathrm{ha}^{-1}$ ) was left after cutting for the full-tree harvesting treatment. We hypothesized that fungal

117 community structure will change, and that fungal diversity will be lower after the full-tree forest

118 harvesting treatment, since intensive harvesting of residual biomass around stumps would cause

119 a decrease in the resources available for wood-inhabiting fungi and a resulting decline in fungal 120 diversity.

121

\section{MATERIALS \& METHODS}

123 Study Site

124 We sampled fungi from stumps at the Island Lake Experimental Research Site $\left(47^{\circ} 42^{\prime} \mathrm{N}, 83^{\circ}\right.$

$12536^{\prime}$ W), 30 km south-west of Chapleau, Ontario, Canada (Fig. 1A). The Island Lake

126 Experimental Research site is a replicated silvicultural experiment where residual woody

127 material including fine and coarse woody debris, cut stumps and even organic material and the

128 upper layers of soil were removed in three increasingly intensive biomass removal treatments

129 which were applied following clear-felling. For our study, we focused on only two of these

130 treatments; standard tree-length harvesting whereby trees were delimbed at the stump and all

131 logging residuals were left on site (Fig. 1B) and full-tree biomass harvesting whereby all trees

132 including non-merchantable trees were cut and removed from the site prior to being delimbed

133 (Fig 1C). At our sampling locations, in the tree-length treatment, an average of $84 \mathrm{~m}^{3} \mathrm{ha}^{-1}$ (SE=

$\left.13415 \mathrm{~m}^{3} \mathrm{ha}^{-1}\right)$ of residual biomass was left on the soil, while this volume was $28 \mathrm{~m}^{3} \mathrm{ha}^{-1}(\mathrm{SE}=3$

$\left.135 \mathrm{~m}^{3} \mathrm{ha}^{-1}\right)$ in the full-tree treatment. The tree-length treatment had 3.2-4.3 times more total

136 deadwood biomass and 2.7-3.1 times more coarse woody material ( $>10 \mathrm{~cm}$ diameter) volume

137 than the full-tree treatment (Kwiaton and al., 2014). 
139 study the remaining more intensive treatments where stumps were removed (stump removal and

140 blading). All treatments were replicated five times in a randomized complete block design. The

141 initial clear felling took place over the winter of 2010-2011 and was carried out using a Tigercat

142 870C feller plug and a Caterpillar 545C grapple skidder (Kwiaton et al., 2014). Prior to

143 harvesting, the site was dominated by jack pines (Pinus banksiana Lamb.) that were planted in

1441960 and had not been subjected to pre-commercial thinning. Following biomass removal, sites

145 were replanted with both jack pine and black spruce (Picea mariana (Mill.) BSP) with a target

146 stocking density of 3300 stems/ha. The average annual temperature at this site is $1.7^{\circ} \mathrm{C}$ and the

147 average annual precipitation is $797 \mathrm{~mm}$ (532 $\mathrm{mm}$ of rain and $277 \mathrm{~mm}$ of snow).

149 Fungal community sample collection

150 Fungi were collected from stumps in September 2016 (5 years post-harvest). We collected

151 samples from five randomly selected stumps in five blocks in each of the tree-length and full-tree

152 treatments, yielding a total of 50 samples (25 in each treatment). Fungi were collected from

153 sawdust (ca. $100 \mathrm{mg}$ ) extracted from stumps using a $1 \mathrm{~mm}$ diameter drill. Two sawdust samples

154 were taken from the sides of each of the stumps, including wood and bark, and pooled together.

155 Surfaces of stumps were not surface sterilized in any way. Samples were placed directly in tubes

156 containing a cetyltrimethylammonium bromide (CTAB) solution after collection. The drill bit

157 was sterilized between stumps using a blowtorch for twenty seconds followed by a 100\% bleach

158 wash to avoid contamination. All samples were transported to the lab and stored at $-20^{\circ}$ until

159 further processing. The use of the CTAB solution to preserve and extract fungal DNA has been

160 recommended (Van Burik et al., 1998; Kim et al., 1990), since its use makes it possible to 
161 denature and eliminate contaminants of proteins (Blin and Stafford, 1976). We followed the

162 CTAB extraction protocol used by DeBellis and Widden (2006). The first step of the extraction

163 consisted of breaking up sawdust pieces using a bead beater (MiniBead Beadbeater-16 (BioSpec

164 Products, Bartlesville, OK, USA) for 6 minutes with shaking speeds of 2000-3800

165 strokes/minute using sterilized 2.3mm diameter stainless steel beads (BioSpec Products).

166

167 Fungal community sequencing

168 We prepared samples for high throughput sequencing by amplifying the internal transcribed

169 spacer region using the fungal specific primer ITS1F (Gardes and Bruns 1993) and ITS2 (White

170 et al 1990). The primers were designed for sequencing on the Illumina MiSeq platform by

171 combining an Illumina sequencing adapter, a 12 nucleotide barcode to identify each sample, and

172 the ITS1F-ITS2 primer sequences (ITS forward : 5' -CAAGCAGAAG

173 ACGGCATACGAGATG TGACTGGAGTTCAGACG TGTGCTCTTCCGATCT

174 xxxxxxxxxxxx CTTGGTCATTTA GAGGAAGTAA 3', and ITS2 Reverse : 5' -

175 AATGATACGGCG ACCACCGAGATCT ACACTCTTTCCCTAC ACGA

176 CGCTCTTCCGATCT xxxxxxxxxxxx GCTGCGTTCT TCATCGATGC - 3'. The symbol $x$

177 represents the 12 barcode nucleotides used for demultiplexing of samples after sequencing). The

178 polymerase chain reaction (PCR) reactions included 5ul of buffer 5xHF (Thermo Scientific),

$1790.75 \mathrm{M}$ of DMSO, $0.5 \mathrm{M}$ of dNTP $(10 \mathrm{uM}), 0.5 \mathrm{M}$ of the reverse and forward primer, $0.25 \mathrm{M}$ of

180 polymerase phusion Hot start II and molecular grade water in a final volume of $25 \mathrm{ul}$.

$181 \quad$ PCR reactions were performed following initial denaturation at $98^{\circ} \mathrm{C}$ for $30 \mathrm{~s}$, followed

182 by 35 cycles of $15 \mathrm{~s}$ at $98^{\circ} \mathrm{C}, 30 \mathrm{~s}$ at $60^{\circ} \mathrm{C}$ and $30 \mathrm{~s}$ at $72^{\circ} \mathrm{C}$, with a final elongation phase for 10

$183 \mathrm{~min}$ at $72^{\circ} \mathrm{C}$. PCR products were cleaned and normalized with Invitrogen Sequalprep PCR clean- 
184 up and normalization kit. The resulting normalized samples were pooled and sequenced on an

185 Illumina Mi-Seq using MiSeq ${ }^{\circledR}$ Reagent Kit v3 (paired end 300 base pair) at the Université de 186 Montréal.

Sequencing of normalized samples yielded a total of 479,034 sequences from 49 samples.

188 We processed raw sequence data using pear (Zhang et al., 2013) and QIIME version 1.9.1

189 (Caporaso et al., 2010) software to assemble paired end sequences into a single continuous

190 sequence, demultiplex sequences based on the sample they were associated with, and to

191 eliminate low quality sequences using a quality control cut-off that eliminated all sequences with

192 a mean quality score of 30 or less. We then binned the remaining sequences into operational

193 taxonomic units (OTUs) using a 97\% sequence similarity cutoff using the uclust algorithm

194 (Edgar, 2010). We determined the taxonomic identity of each OTU using the RDP algorithm by

195 comparison with the UNITE sequence database (Nilsson et al., 2011) as implemented in QIIME.

196 We then identified the potential ecological role of the fungi detected in our samples by

197 comparing OTUs that could be identified taxonomically to the species level with various

198 literature sources (Boulet, 2003; Kebli et al., 2012; Stokland and Larsson, 2011; Van der wal et

199 al., 2017). We removed all singleton OTUs, all samples containing less than 1,350 sequences and

200 one outlier sample from all further analyses, leaving a total of 56,700 sequences from 42 samples

201 after quality control and processing. We identified 1813 OTUs from these sequences and

202 samples. We were able to identify 625 of these OTUs to the taxonomic rank of species. 203

204 Data analyses

205 In order to assure our sampling effort was sufficient to characterize the diversity of fungal

206 communities, we calculated rarefaction curves for each sample to determine how the number of 
207 OTUs scaled with the number of sequences per sample. Rarefaction curves were based on 100 208 random iterations per sample.

209 We calculated the alpha diversity of fungal communities using the Shannon index

210 (Shannon and Weaver, 1949) based on the rarefied relative abundances of OTUs. We compared

211 Shannon diversity between treatments using linear mixed models where biomass removal

212 treatment was treated as a fixed effect and experimental block was treated as a random effect.

213 We quantified the taxonomic composition of fungal communities at different taxonomic

214 ranks in each treatment by calculating the mean abundance of OTUs identified at the rank of

215 phylum, class, order, family, genus and species and comparing the relative abundances of each

216 taxon between treatments using ANOVA tests on log-transformed abundance data.

217 To visualize the variation in fungal communities between treatments, non-metric

218 multidimensional scaling (NMDS) analysis calculated from Hellinger transformed OTU data for

219 communities was used, and the significance of the observed differences was determined using a 220 permutational multivariate ANOVA (PERMANOVA; Anderson et al., 2001). The initial sample

221 by OTU matrix rarefied to 1350 sequences per sample was converted to a Bray-Curtis

222 dissimilarity for both analyses.

For the PERMANOVA analysis, experimental block was included as a grouping variable

224 for permutations. A two-dimensional NMDS failed to converge and had high stress (26.6 \%), 225 and so we carried out a NMDS with three dimensions to obtain a stress of $17.8 \%$; this three226 dimensional NMDS was used for subsequent analyses. In these analyses, we used all OTUs, 227 regardless of whether these OTUs could be resolved to recognized, named species.

228 In order to detect taxa or OTUs that were more abundant in the full-tree or tree-length

229 treatment, we used the DESeq2 package (Love et al., 2014) to quantify differences in OTU and 
230 species abundances between treatments. For this analysis, the non-rarified community matrix

231 was used but all OTUs found in 3 or less samples were removed from the matrix prior to the

232 analysis. We used an adjusted P-value cut-off of 0.05 to consider an OTU or species as

233 significantly differentially associated with one of the treatments.

234 Analyses were done using R (Team, R. (2013)) with packages picante (Kembel et al.,

235 2010), vegan (Oksanen et al., 2007) and ggplot2 (Wickham, 2016), DEseq2 (Love and al., 2014),

236 biom (McMurdie 2014), nlme (Pinheiro et al., 2014), multcomp (Hothorn et al., 2016), devtools

237 (Wickham et al., 2015), and seqtools (Rasmussen, 2002).

238

239 RESULTS

240 Once the community dataset was rarefied to 1350 sequences per sample and the outlier sample

241 was removed, a total of 42 samples and 661 OTUs remained. Rarefaction curves of the number

242 of OTUs versus number of sequences in different samples demonstrated that our sampling effort

243 was sufficient to quantify the diversity of the wood inhabiting fungi present in the residual

244 stumps of the two treatments, as the observed number of OTUs within each sample reached a

245 plateau at a lower number of sequences per sample than the number used for our analyses $(1,350$

246 sequences per sample) (supplementary Fig.1).

247 The Shannon diversity of fungal OTUs per sample was marginally lower (linear mixed

248 model; $F_{1,37}=3.62, P$ value $\left.=0.06\right)$ in the full-tree treatment $(1.91 \pm 0.66)$ compared to the tree-

249 length treatment $(2.31 \pm 0.59)$. Block as a random effect explained only $0.004 \%$ of the variance

250 in diversity. We did not detect any statistically significant differences in the abundance of fungal

251 taxa considering all named taxa at the ranks of phylum, class, order, family, and genus

252 (ANOVAs of log-transformed relative abundance of each taxon between treatments for 
253 taxonomic ranks including phylum, class, order, family and genus; all P-values $>0.05$ ). The

254 most abundant fungal phyla across all communities collected from stumps after residual

255 harvesting were Basidiomycota ( $70 \%$ of sequences) and Ascomycota (30\% of sequences).

256 The most abundant OTUs across both treatments included Perenniporia subacida (11\%),

257 an unidentified fungus OTU $2512(11 \%)$ and Scytinostorma sp (10\%). The relative abundance of

258 the most abundant fungal taxa in each treatment are presented in Table 1. Several taxonomically

259 unidentified OTUs were among the most abundant OTUs (Table 1). None of the most abundant

260 species found in our study are known to be pathogens but some could be unknown.

261 There were no significant differences in fungal community composition between

262 treatments (PERMANOVA test on Bray-Curtis dissimilarities; $\mathrm{r}^{2}=0.04, P$ value $=0.2$ ). The

263 variation in the original dissimilarities explained by the three axes of the NMDS was $11 \%$

264 (supplementary Fig.2). While there were no differences in overall community composition

265 between treatments, some OTUs and species were differentially abundant in one of the two

266 treatments (Table 2). For example, the species Peniophorella pallida, Tephromela sp and

267 Trichoderma citrinoviride were found to be more abundant in the full-tree treatment (-5.14,

$268-3.54,-2.71 \log$ fold change value respectively (Table 2)). Conversely, Phlebia lavida, an

269 unidentified Ascomycota and Cladophialophora chaetospira are examples of species found

270 much more abundantly in the tree-length treatment $(3.68,1.81,1.65$ log-fold change values

271 respectively (Table 2)). For the majority of the nineteen species that were found to be

272 differentially abundant between treatments, we were unable to find any information on their

273 ecology or pathogenicity (Table 2). The pathogen Serpula himantioides was differentially more

274 abundant in the full-tree treatment. 


\section{DISCUSSION}

277 Contrary to our hypothesis, the diversity and composition of wood-inhabiting fungal

278

279

280

281

282

283

284

285

286

287

288

289

290

291

292

293

294

295

296

297

298

communities in residual stumps were not significantly influenced by full-tree harvesting five

years after harvest. It is important to stress that in both tree-length and full-tree harvest

treatments, we sampled fungal communities in residual stumps and not residual logging slash for

the simple reasons smaller diameter logging residual was removed at the time of treatment. It is

well documented that residual slash does serve as an important substrate for certain species

(Kruys and Jonsson, 1999; Juutilainen et al., 2011; Küffer and al., 2008). In contrast to our

findings studies from Europe that demonstrate strong effects of biomass removal on fungal

composition often come from landscapes with a long history of intensive management that have

yet to be created in North America (Gu et al., 2002; Östlund, Zackrisson and Axelsson, 1997).

Forests with a longer history of logging likely contain less deadwood (Stokland et al., 2001),

which for saproxylic fungi may result in habitat loss with ensuing effects related to isolation of

individual habitat patches and overall reduced area of forests with old growth characteristics

(Penttilä et al., 2006). Persistent reductions in volumes of dead wood have been shown to reduce the diversity of wood-inhabiting fungi (Siitonen, 2001). The minimum thresholds for harvesting biomass in Europe range between $6.1 \mathrm{~m}^{3} \mathrm{ha}^{-1}$ (Friedman and Walheim, 2000) and $13 \mathrm{~m}^{3} \mathrm{ha}^{-1}$ (Gibb et al., 2005) depending on harvest intensity.

Basidiomycetes and Ascomycetes dominated the fungal communities in the residual

stumps in our study, a result that is consistent with all types of fungal survey work on dead wood (Lindner et al., 2006; Rajala et al., 2010; Rajala et al., 2012). Many of the most abundant species and OTUs identified in our study, for which ecological data were available, were identified as white and brown rot fungi. These groups are characterized by their enzymatic ability to degrade 
299 wood (Erikson et al., 1995) and are considered as the main decomposers of deadwood (Stokland

300 et al., 2012). The most abundant species found in our study was P. subacida, a white rot fungus.

301 This species is often reported to be present in stumps and residual branches in logged areas

302 (Kubart et al., 2016; Penttilä et al., 2004; Brazee et al., 2012), but it is generally not one of the

303 most abundant species. Interestingly, despite its abundance at our study site, $P$. subacida is a

304 vulnerable species of conservation concern in Europe (Kubart et al., 2016; Parmasto, 2001). The

305 relative abundance of this species in our study and its scarcity in Europe are consistent with the

306 idea that prolonged and intensive forest management has had an impact on the abundance of

307 wood-inhabiting fungi species; in Europe, $P$. subacida is more common in forests that have

308 limited impacts from forestry (Penttilä et al., 2006).

309 Brown rot fungi were not found to be abundant in this study, which is surprising given

310 that brown rot fungi are more numerous in many studies on fungal diversity on the dead wood

311 (Rayner and Boddy 1998, Rajala et al., 2012). Brown rot fungi are considered the main

312 decomposers of the boreal forest (Renval, 1995) but this was based on the identification of

313 fruiting bodies on conifer wood. Similarly, while ectomycorrhizal fungi can be retained by the

314 root and stumps several years after forest harvesting and are ecologically important in boreal

315 forests (Hagerman et al., 1999; Heinonsalo et al., 2007), we found only one of the 20 most

316 abundant OTUs per treatment in our study to be mycorrhizal (Table 1). None of the most

317 abundant species in this study are known to be pathogens.

318 While the overall diversity and composition of fungal communities did not differ between

319 harvesting treatments, there were individual fungal OTUs and species that were differentially

320 abundant in one treatment. The abundance of 19 fungal OTUs differed significantly between

321 treatments, but information about their ecology could be found only for half of these species and 
322 ecologically important fungi such as mycorrhizal fungi were found in association with both the

323 full-tree and tree-length treatments. The pathogenic species $S$. himantioides. was more abundant

324 on stumps in the full-tree treatment. This species is primarily a pathogen of conifers (Seehann,

325 1986) that can cause a significant loss of tree volume (Chakravarty, 1995) and cause root tissue

326 death (Seehann, 1986). Follow-up studies will be required to determine if the association of this

327 pathogen with the full-tree treatment will lead to increased rates of infection in this treatment.

328

329 In general, our study highlights the advantages and limitations of molecular approaches to

330 quantify fungal community structure. Molecular analyses of the fungal taxa present in deadwood

331 such as the present study detect a greater diversity of fungi than do studies based on the

332 identification of fungal fruiting bodies or morphological identification of fungi in wood

333 (Ovaskainen et al., 2010; Kubartová et al. 2012). However, molecular studies of fungal

334 communities are currently limited by the lack of taxonomic resolution for many OTUs and the

335 lack of information on the ecology of most of these taxa (Rajala et al., 2012, Ovaskainen et al.,

336 2010). Alternatively, fungal community studies based on sporocarp surveys have other

337 limitations as it will only detect species that form ephemeral, above-ground fruiting bodies

338 (Ovaskainen et al., 2013), resulting with the vast majority of fungal taxa remaining unidentified

339 (Allmér et al., 2005). Because very little is known on the ecology of fungi identified with

340 environmental sequencing approaches beyond making broad categorizations such as rot fungi or

341 mycorrhizal fungi, our ability to infer ecological differences among communities is limited even

342 though molecular studies provide a wider range of fungal diversity. There is thus a pressing need

343 to develop databases of the ecology of different fungal taxa that can be used to understand

344 community and ecosystem responses to forest harvesting. 


\section{CONCLUSIONS}

346 Overall, our results do not suggest any difference in the diversity or structure of fungal

347 communities between full-tree and tree-length treatments. However, some fungal species and

348 OTUs were more abundant in one or the other of the two treatments. This study took place 5

349 years after harvesting in a forest dominated by a single tree species. Variation among host trees

350 and decay stages of dead wood are important factors in the structuring of fungal communities.

351 Future studies will be required to understand the potential long-term impacts of forest harvesting 352 on fungal diversity.

353

\section{Acknowledgements}

355 We would like to thank Paul Hazlett and Rob Fleming for the opportunity to conduct research at 356 the Island Lake Biomass Harvest Experiment, Kerry Wainio-Keizer for help sampling stumps 357 and logistics related to field work, and Melanie Desrochers for help generating the map of study 358 sites used in Fig 1.

\section{REFERENCES}

361 Allmér, J., Vasiliauskas, R., Ihrmark, K., Stenlid, J., \& Dahlberg, A. (2005). Wood-inhabiting

362 fungal communities in woody debris of Norway spruce (Picea abies (L.) Karst.) as

363 reflected by sporocarps mycelial isolations and T-RFLP identification. FEMS

364 Microbiology Ecology, 55(1), 57-67.

365 Anderson, M. J. (2001). A new method for non-parametric multivariate analysis of variance.

366 Austral Ecology, 26(1), 32-46. 
367 Bader, P., Jansson, S., \& Jonsson, B. G. (1995). Wood-inhabiting fungi and substratum decline

368 in selectively logged boreal spruce forests. Biological Conservation, 72(3), 355-362.

369 Battigelli, J. P., Spence, J. R., Langor, D. W., \& Berch, S. M. (2004). Short-term impact of forest

370 soil compaction and organic matter removal on soil mesofauna density and oribatid mite

371 diversity. Canadian Journal of Forest Research, 34(5), 1136-1149.

372 Blin, N., \& Stafford, D. W. (1976). A general method for isolation of high molecular weight DNA from eukaryotes. Nucleic Acids Research, 3(9), 2303-2308.

Brazee, N. J., Lindner, D. L., D’Amato, A. W., Fraver, S., Forrester, J. A., \& Mladenoff, D. J.

375

376

377

378

380 (2014). Disturbance and diversity of wood-inhabiting fungi: effects of canopy gaps and downed woody debris. Biodiversity and Conservation, 23(9), 2155-2172.

Brazee, N. J., Lindner, D. L., Fraver, S., D'Amato, A. W., \& Milo, A. M. (2012). Woodinhabiting, polyporoid fungi in aspen-dominated forests managed for biomass in the US Lake States. Fungal Ecology, 5(5), 600-609.

Boddy, L., \& Watkinson, S. C. (1995). Wood decomposition, higher fungi, and their role in nutrient redistribution. Canadian Journal of Botany, 73(S1), 1377-1383.

Boulet Bruno. (2003). Les champignons des arbres de l'est de l'Amérique du Nord. Sainte-Foy: Publications du Québec. Canada. Ressources naturelles Canada, \& Québec (Province). Ministère des ressources naturelles, de la faune et des parcs.

Caporaso, J. G., Kuczynski, J., Stombaugh, J., Bittinger, K., Bushman, F. D., Costello, E. K., ... \& Huttley, G. A. (2010). QIIME allows analysis of high-throughput community sequencing data. Nature methods, 7(5), 335-336.

Caruso, A., \& Rudolphi, J. (2009). Influence of substrate age and quality on species diversity of lichens and bryophytes on stumps. The Bryologist, 112(3), 520-531. 
390 Chakravarty, P. (1995). Decay and stain fungi of North American conifers with special reference

391 to the prairie provinces (Vol. 132). Natural Resources Canada, Canadian Forest Service,

$392 \quad$ Northern Forestry Centre.

393 DeBellis, T., \& Widden, P. (2006). Diversity of the small subunit ribosomal RNA gene of the

394 arbuscular mycorrhizal fungi colonizing Clintonia borealis from a mixed-wood boreal

395 forest. FEMS microbiology ecology, 58(2), 225-235.

396 Debeljak, M. (2006). Coarse woody debris in virgin and managed forest. Ecological Indicators, $397 \quad 6(4), 733-742$.

398 de Jong, J., Akselsson, C., Egnell, G., Löfgren, S., Olsson, B.A., (2017). Realizing the energy

399 potential of forest biomass in Sweden - How much is environmentally sustainable? Forest

$400 \quad$ Ecology and Management 383: 3-16.

401 de Jong, J. \& Dahlberg, A., (2017). Impact on species of conservation interest of forest

402 harvesting for bioenergy purposes. Forest Ecology and Management 383: 37-48.

403 Edgar, R. C. (2010). Search and clustering orders of magnitude faster than BLAST.

404 Bioinformatics, 26(19), 2460-2461.

405 Eräjää, S., Halme, P., Kotiaho, J. S., Markkanen, A., \& Toivanen, T. (2010). The volume and

406 composition of dead wood on traditional and forest fuel harvested clear-cuts. Silva

407 Fennica, vol 44 no 2 article ID 150.

408 Erickson, H. E., Edmonds, R. L., \& Peterson, C. E. (1985). Decomposition of logging residues in

409 Douglas-fir, western hemlock, Pacific silver fir, and ponderosa pine ecosystems. Canadian

$410 \quad$ Journal of Forest Research, 15(5), 914-921. 
411 Fukasawa, Y., Osono, T., \& Takeda, H. (2009). Microfungus communities of Japanese beech

$412 \operatorname{logs}$ at different stages of decay in a cool temperate deciduous forest. Canadian Journal of $413 \quad$ Forest Research, 39(8), 1606-1614.

414 Fridman, J., \& Walheim, M. (2000). Amount, structure, and dynamics of dead wood on managed 415 forestland in Sweden. Forest Ecology and Management, 131(1), 23-36.

416 Garbelotto, M., \& Gonthier, P. (2013). Biology, epidemiology, and control of Heterobasidion 417 species worldwide. Annual Review of Phytopathology, 51, 39-59.

418 Gardes, M., Bruns, T.D. (1993). ITS primers with enhanced specificity for basiodiomycetes.pdf. $419 \quad$ Molecular Ecology 2:113-118

420 GEA. (2012). Global energy assessment-toward a sustainable future. Scenario Database 421 Connected to Assessment, Cambridge University Press.

422 Gibb, H., Ball J.P., Johansson T., Atlegrim, O., Hjalten J., Danell, K. (2005) Effects of 423 management on coarse woody debris volume and composition in boreal forests in northern Sweden. Scandinavian Journal of Forest Research 20:213-222.

Gu, W., Heikkilä, R., \& Hanski, I. (2002). Estimating the consequences of habitat fragmentation on extinction risk in dynamic landscapes. Landscape Ecology, 17(8), 699-710. of clear-cut logging on the diversity and persistence of ectomycorrhizae at a subalpine forest. Canadian Journal of Forest Research, 29(1), 124-134.

Hanski, I. (1998). Metapopulation dynamics. Nature, 396(6706), 41.

431 Hanski, I. (2005). The shrinking world: ecological consequences of habitat loss (Vol. 14).

432 Oldendorf/Luhe: International Ecology Institute. 
433 Harmon, M. E., Franklin, J. F., Swanson, F. J., Sollins, P., Gregory, S. V., Lattin, J. D., ... \& 434 Lienkaemper, G. W. (1986). Ecology of coarse woody debris in temperate ecosystems. Advances in Ecological Research, 15, 133-302.

436

440

441

442

443

444

445 446

447

448

449

450

451

452
Heinonsalo, J., Koskiahde, I., \& Sen, R. (2007). Scots pine bait seedling performance and root colonizing ectomycorrhizal fungal community dynamics before and during the 4 years after forest clear-cut logging. Canadian Journal of Forest Research, 37(2), 415-429.

Holeksa, J., Zielonka, T., \& Żywiec, M. (2008). Modeling the decay of coarse woody debris in a subalpine Norway spruce forest of the West Carpathians, Poland. Canadian Journal of Forest Research, 38(3), 415-428.

Hothorn, T., Bretz, F., Westfall, P., Heiberger, R. M., Schuetzenmeister, A., Scheibe, S., \& Hothorn, M. T. (2016). Package 'multcomp'. Simultaneous inference in general parametric models. Project for Statistical Computing, Vienna, Austria.

Jonsell, M. (2008). Saproxylic beetle species in logging residues: which are they and which residues do they use? Norwegian Journal of Entomology, 55(1), 109.

Jonsell, M., \& Schroeder, M. (2014). Proportions of saproxylic beetle populations that utilise clear-cut stumps in a boreal landscape-biodiversity implications for stump harvest. Forest Ecology and Management, 334, 313-320.

Jonsson, B. G., \& Kruys, N. (2001). Ecology of coarse woody debris in boreal forests: future research directions. Ecological Bulletins, (49), 279-281.

Juutilainen, K., Halme, P., Kotiranta, H., \& Mönkkönen, M. (2011). Size matters in studies of dead wood and wood-inhabiting fungi. Fungal Ecology 4, 342-349.

Peer] reviewing PDF | (2019:05:37818:1:0:NEW 7 Oct 2019) 
454 Kebli, H., Brais, S., Kernaghan, G., \& Drouin, P. (2012). Impact of harvesting intensity on

455

456

457

458

460

461

462

463

464

465

466

467

468

469

470

471

472

473

474

475 wood-inhabiting fungi in boreal aspen forests of Eastern Canada. Forest Ecology and Management, 279, 45-54.

Kembel, S. W., Cowan, P. D., Helmus, M. R., Cornwell, W. K., Morlon, H., Ackerly, D. D., ... \& Webb, C. O. (2010). Picante: R tools for integrating phylogenies and ecology. Bioinformatics, 26(11), 1463-1464.

Kim, W. K., Mauthe, W., Hausner, G., \& Klassen, G. R. (1990). Isolation of high molecular weight DNA and double-stranded RNAs from fungi. Canadian Journal of Botany, 68(9), 1898-1902.

Kotiranta, H., Junninen, K., Halme, P., Kytövuori, I., von Bonsdorff, T., Niskanen, T. \& Liimatainen, K. 2019. Kääväkkäät - Aphyllophoroid fungi. In: Hyvärinen, E., Juslén, A., Kemppainen, E., Uddström, A. \& Liukko, U.-M. (2019). The Red List of Finnish species 2019. Ministry of Environment \& Finnish Environment Institute. Helsinki. p. 234-247.

Kruys, N., \& Jonsson, B. G. (1999). Fine woody debris is important for species richness on logs in managed boreal spruce forests of northern Sweden. Canadian Journal of Forest Research, 29(8), 1295-1299.

Kubart, A., Vasaitis, R., Stenlid, J., \& Dahlberg, A. (2016). Fungal communities in Norway spruce stumps along a latitudinal gradient in Sweden. Forest Ecology and Management, $371,50-58$.

Kubartová, A., Ottosson, E., Dahlberg, A., \& Stenlid, J. (2012). Patterns of fungal communities among and within decaying logs, revealed by 454 sequencing. Molecular Ecology, 21(18), 4514-4532. 
476 Küffer, N., Gillet, F., Senn-Irlet, B., Job, D., \& Aragno, M. (2008). Ecological determinants of 477 fungal diversity on dead wood in European forests. Fungal Diversity, 30, 83-95.

478 Kwiaton, M., Hazlett, P., Morris, D., Fleming, R.L., Webster, K., Venier, L., Aubin, I. (2014).

479 Island Lake Biomass Harvest Research and Demonstration Area: Establishment report.

480 Natural Resources Canada, Canadian Forest Service, Great Lakes Forestry Centre, Sault

481 Ste. Marie, Ont., Information Report GLC-X-11.

482 Laiho, R., \& Prescott, C. E. (2004). Decay and nutrient dynamics of coarse woody debris in

483 northern coniferous forests: a synthesis. Canadian Journal of Forest Research, 34(4), 763-

484 777.

485

Lindner, D. L., Burdsall Jr, H. H., \& Stanosz, G. R. (2006). Species diversity of polyporoid and 486 corticioid fungi in northern hardwood forests with differing management histories. Mycologia, 98(2), 195-217.

Love, M., Anders, S., \& Huber, W. (2014). Differential analysis of count data-the DESeq2 package. Genome Biol, 15, 550.

Mabee, W. E., \& Saddler, J. N. (2010). Bioethanol from lignocellulosics: Status and perspectives in Canada. Bioresource Technology, 101(13), 4806-4813.

McMurdie, P. J. Biom-Format Team (2014). biom: An interface package (beta) for the BIOM file format.

Müller, J., Engel, H., \& Blaschke, M. (2007). Assemblages of wood-inhabiting fungi related to 
497 Nilsson, R. H., Abarenkov, K., Larsson, K. H., \& Kõljalg, U. (2011). Molecular identification of 498 fungi: rationale, philosophical concerns, and the UNITE database. Open Applied 499 Informatics Journal, 5, 81-86.

500 Nilsson, S. G., Hedin, J., \& Niklasson, M. (2001). Biodiversity and its assessment in boreal and 501 nemoral forests. Scandinavian Journal of Forest Research, 16(S3), 10-26.

502 Nordén, B., Ryberg, M., Götmark, F., \& Olausson, B. (2004). Relative importance of coarse and 503 fine woody debris for the diversity of wood-inhabiting fungi in temperate broadleaf forests. 504 Biological Conservation, 117(1), 1-10.

505 Nordén, J., Penttilä, R., Siitonen, J., Tomppo, E., \& Ovaskainen, O. (2013). Specialist species of 506 wood-inhabiting fungi struggle while generalists thrive in fragmented boreal forests.

$507 \quad$ Journal of Ecology, 101(3), 701-712.

508 Ódor, P., Heilmann-Clausen, J., Christensen, M., Aude, E., Van Dort, K. W., Piltaver, A., ... \&

509 Van Hees, A. F. M. (2006). Diversity of dead wood inhabiting fungi and bryophytes in 510 semi-natural beech forests in Europe. Biological Conservation, 131(1), 58-71.

511 Oksanen, J., Kindt, R., Legendre, P., O’Hara, B., Stevens, M. H. H., Oksanen, M. J., \& Suggests,

512 M. A. S. S. (2007). The vegan package. Community ecology package, 10, 631-637.

513 Oliva, J., Thor, M., \& Stenlid, J. (2010). Long-term effects of mechanized stump treatment 514 against Heterobasidion annosum root rot in Picea abies. Canadian Journal of Forest $515 \quad$ Research, 40(6), 1020-1033.

516 Östlund, L., Zackrisson, O., \& Axelsson, A. L. (1997). The history and transformation of a 517 Scandinavian boreal forest landscape since the 19th century. Canadian Journal of Forest $518 \quad$ Research, 27(8), 1198-1206. 
519 Ovaskainen, O., Nokso-Koivisto, J., Hottola, J., Rajala, T., Pennanen, T., Ali-Kovero, H., ... \&

520 Larsson, K. H. (2010). Identifying wood-inhabiting fungi with 454 sequencing-what is the

521 probability that BLAST gives the correct species? Fungal Ecology, 3(4), 274-283.

522 Ovaskainen, O., Schigel, D., Ali-Kovero, H., Auvinen, P., Paulin, L., Nordén, B., \& Nordén, J.

523 (2013). Combining high-throughput sequencing with fruit body surveys reveals contrasting 524 life-history strategies in fungi. The ISME journal, 7(9), 1696-1709.

525 Parmasto, E. (2001). Fungi as indicators of primeval and old-growth forests deserving protection. 526 Fungal Conservation, Issues and Solutions, 81-88.

527 Penttilä, R., Lindgren, M., Miettinen, O., Rita, H., \& Hanski, I. (2006). Consequences of forest 528 fragmentation for polyporous fungi at two spatial scales. Oikos, 114(2), 225-240.

529 Penttilä, R., Siitonen, J., \& Kuusinen, M. (2004). Polypore diversity in managed and old-growth $530 \quad$ boreal Picea abies forests in southern Finland. Biological Conservation, 117(3), 271-283.

531 Pinheiro, J., Bates, D., DebRoy, S., \& Sarkar, D. (2014). R Core Team (2014) nlme: linear and 532 nonlinear mixed effects models. R package version 3.1-117. Available at $h$ ttp://CRAN. R533 project. org/package= nlme.

534 Piri, T., \& Korhonen, K. (2001). Infection of advance regeneration of Norway spruce by 535 Heterobasidion parviporum. Canadian Journal of Forest Research, 31(6), 937-942.

536 Rajala, T., Peltoniemi, M., Pennanen, T., \& Mäkipää, R. (2010). Relationship between wood537 inhabiting fungi determined by molecular analysis (denaturing gradient gel electrophoresis) and quality of decaying logs. Canadian Journal of Forest Research, 40(12), 2384-2397.

539 Rajala, T., Peltoniemi, M., Pennanen, T., \& Mäkipää, R. (2012). Fungal community dynamics in 540 relation to substrate quality of decaying Norway spruce (Picea abies [L.] Karst.) logs in $541 \quad$ boreal forests. FEMS Microbiology Ecology, 81(2), 494-505. 
542 Rasmussen, S. W. (2002). SEQtools, a software package for analysis of nucleotide and protein $543 \quad$ sequences.

544 Rayner, A.D.M., Boddy, L. (1997). Fungal Decomposition of Wood: Its Biology and Ecology. $545 \quad$ Bath Press, Bath

546 Renvall, P. (1995). Community structure and dynamics of wood-rotting Basidiomycetes on 547 decomposing conifer trunks in northern Finland. Karstenia, 35, 1-51.

548 Rudolphi, J., \& Gustafsson, L. (2005). Effects of forest-fuel harvesting on the amount of 549 deadwood on clear-cuts. Scandinavian Journal of Forest Research, 20(3), 235-242.

550 Seehann, G. (1986). Butt rot in conifers caused by Serpula himantioides (Fr.) Karst. Forest $551 \quad$ Pathology, 16(4), 207-217.

552 Shannon, C. E., \& Weaver, W. (1949). The mathematical theory of Communication. University 553 of Illinois Press, Champaign.

554 Siitonen, J., Martikainen, P., Punttila, P., \& Rauh, J. (2000). Coarse woody debris and stand 555 characteristics in mature managed and old-growth boreal mesic forests in southern Finland. $556 \quad$ Forest Ecology and Management, 128(3), 211-225.

557 Siitonen, J. (2001). Forest management, coarse woody debris and saproxylic organisms:

558 Fennoscandian boreal forests as an example. Ecological Bulletins, 11-41.

559 Stokland, J. N. (2001). The coarse woody debris profile: an archive of recent forest history and 560 an important biodiversity indicator. Ecological Bulletins, 71-83.

561 Stokland, J. N., \& Larsson, K. H. (2011). Legacies from natural forest dynamics: Different 562 effects of forest management on wood-inhabiting fungi in pine and spruce forests. Forest 563 Ecology and Management, 261(11), 1707-1721. 
564 Stokland, J. N., Siitonen, J., \& Jonsson, B. G. (2012). Biodiversity in dead wood. Cambridge

$565 \quad$ University Press.

566 Sullivan, T. P., Sullivan, D. S., Lindgren, P. M., Ransome, D. B., Bull, J. G., \& Ristea, C.

567 (2011). Bioenergy or biodiversity? Woody debris structures and maintenance of red-

568 backed voles on clearcuts. Biomass and Bioenergy, 35(10), 4390-4398.

569 Suominen, M., Junninen, K., Heikkala, O. and Kouki, J. (2018). Burning harvested sites

$570 \quad$ enhances polypore diversity on stumps and slash. Forest Ecology and Management 414:

$571 \quad 47-53$.

572 Svensson, M., Johansson, V., Dahlberg, A., Frisch, A., Thor, G., \& Ranius, T. (2016). The

573 relative importance of stand and dead wood types for wood-dependent lichens in managed

$574 \quad$ boreal forests. Fungal Ecology, 20, 166-174.

575 Team, R. C. (2013). R-a language and environment for statistical computing. R Foundation for

$576 \quad$ statistical computing, Vienna, Austria.

577 Toivanen, T., Markkanen, A., Kotiaho, J. S., \& Halme, P. (2012). The effect of forest fuel

578 harvesting on the fungal diversity of clear-cuts. Biomass and Bioenergy, 39, 84-93.

579 Valentín, L., Rajala, T., Peltoniemi, M., Heinonsalo, J., Pennanen, T., \& Mäkipää, R. (2014).

580 Loss of diversity in wood-inhabiting fungal communities affects decomposition activity in

$581 \quad$ Norway spruce wood. Frontiers in Microbiology, 5.

582 Vallauri, D., Andre, J., \& Blondel, J. (2003). Le bois mort, une lacune des forêts gérées. Revue

583 forestière française, 55(2), 99-112.

584 Van Burik, J. A., Schreckhise, R. W., White, T. C., Bowden, R. A., \& Myerson, D. (1998).

585 Comparison of six extraction techniques for isolation of DNA from filamentous fungi.

$586 \quad$ Medical Mycology, 36(5), 299-303. 
587 Van der Wal, A., Gunnewiek, P. K., de Hollander, M., \& de Boer, W. (2017). Fungal diversity

588 and potential tree pathogens in decaying logs and stumps. Forest Ecology and

589 Management, 406, 266-273.

590 Walmsley, J. D., and Godbold, D. L. (2009). Stump Harvesting for Bioenergy - A Review of the $591 \quad$ Environmental Impacts. Forestry, 83(1), 17-38.

592 White, T.J., Bruns T., Lee S., Taylor J. 1990. Amplification and direct sequencing of fungal 593 ribosomal RNA genes for phylogenetics. In: PCR protocols: a guide to methods and 594 applications. New York: Academic Press. 315-322.

595 Wickham, H. (2016). ggplot2: elegant graphics for data analysis. Springer.

596 Wickham, H., \& Chang, W. (2015). Devtools: Tools to Make Developing R Packages Easier, 597 URL http://CRAN. R-project. org/package= devtools. $R$ package version, 1(0), 185.

598 Woodward, S., Stenlid, J., Karjalainen, R., \& Hüttermann, A. (1998). Heterobasidion annosum: 599 Biology, Ecology. Impact and Control. CAB International, Wallingford.

600 Work, T. T., Brais, S., \& Harvey, B. D. (2014). Reductions in downed deadwood from biomass 601 harvesting alter composition of spiders and ground beetle assemblages in jack-pine forests 602 of Western Quebec. Forest Ecology and Management, 321, 19-28.

603 Zhang, J., Kobert, K., Flouri, T., \& Stamatakis, A. (2013). PEAR: a fast and accurate Illumina 604 Paired-End reAd mergeR. Bioinformatics, 30(5), 614-620.

605

606 
Figure 1

Figure1: (A) The study area of the Island Lake Experimental Research site in Ontario, Canada; (B) example of a tree-length harvested plot; (C) example of a full-tree biomass plot
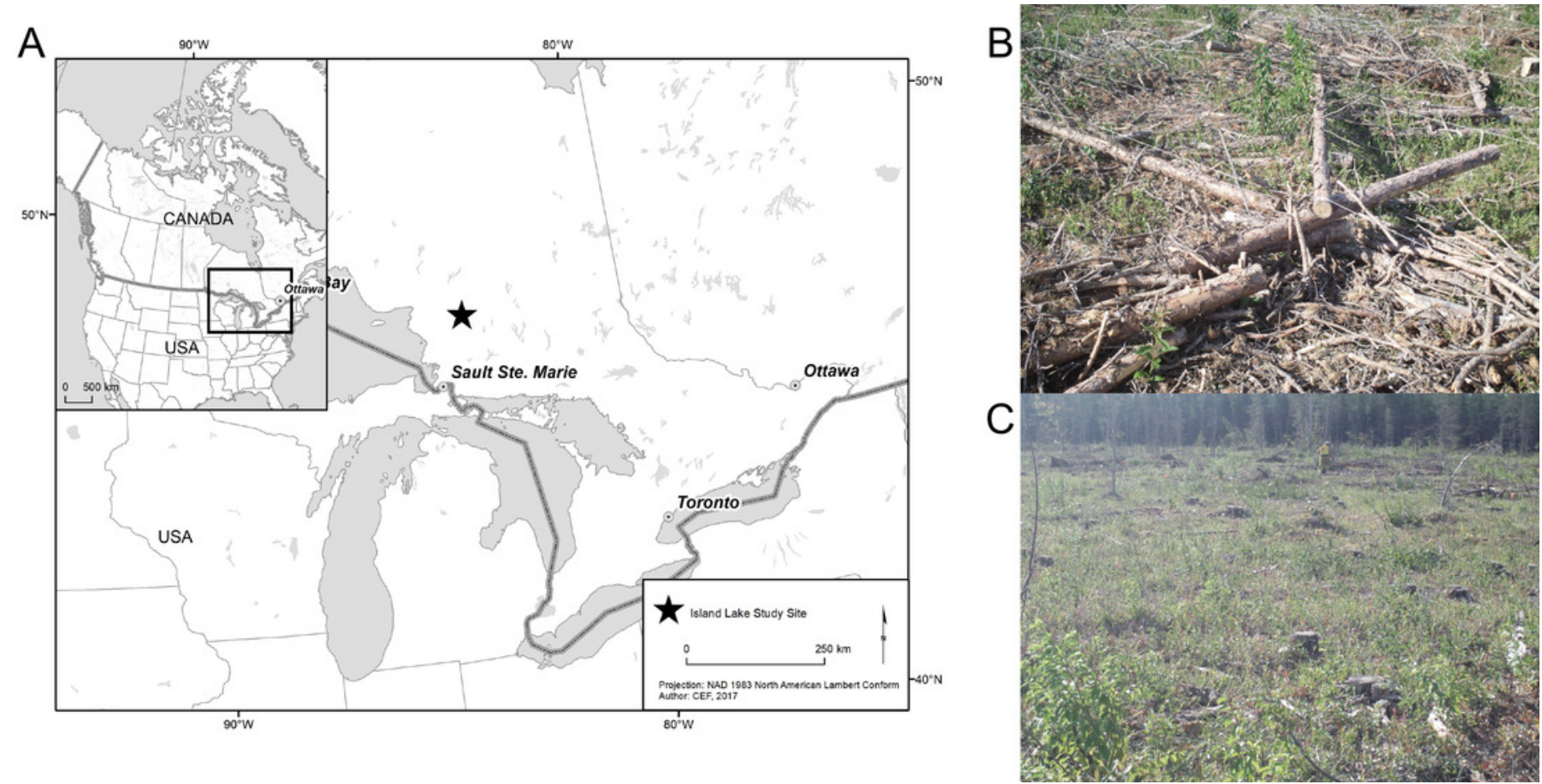


\section{Table $\mathbf{1}$ (on next page)}

The relative abundance and taxonomic identity of the 20 most abundant fungal operational taxonomic units (OTUs) in wood from stumps after full-tree and tree-length treatments at Island Lake.

Information on the ecology, pathogenicity, and wood-decaying ability of fungi was obtained from literature sources (see Methods text for details). For ecology, pathogenicity, and wooddecaying ability, a blank cell indicates we were unable to find information for the species. 


\begin{tabular}{|c|c|c|c|c|c|c|}
\hline \multirow[t]{2}{*}{ Phylum } & \multirow[t]{2}{*}{ Species } & \multirow[t]{2}{*}{ Ecology } & \multirow[t]{2}{*}{ Pathogen } & \multirow[t]{2}{*}{$\begin{array}{l}\text { Wood } \\
\text { decaying } \\
\text { fungi }\end{array}$} & \multicolumn{2}{|c|}{$\begin{array}{l}\text { Relative } \\
\text { abundance } \\
\text { (\% of } \\
\text { sequences) }\end{array}$} \\
\hline & & & & & FT & TL \\
\hline Ascomycota & Hyaloscypha sp & & no & & 0.02 & 0.02 \\
\hline Ascomycota & Capronia leucadendri & & no & & 0.01 & 0.01 \\
\hline Ascomycota & Chalara $s p$ & & & yes & 0.01 & \\
\hline Ascomycota & Unidentified & & & & 0.01 & 0.01 \\
\hline Ascomycota & Cenococcum geophilum & Ectomycorrhiza & & yes & 0.01 & 0.01 \\
\hline Ascomycota & Eurotiomycetes sp & & & yes & 0.01 & 0.01 \\
\hline Ascomycota & Leotiomycetes sp & & & & 0.01 & \\
\hline Ascomycota & Helotiales sp & & & & 0.01 & \\
\hline Ascomycota & Leotiomycetes sp & & & & & 0.01 \\
\hline Basidiomycota & Perenniporia subacida & White rot & no & yes & 0.08 & 0.03 \\
\hline Basidiomycota & Scytinostroma sp & White rot & no & yes & 0.06 & 0.04 \\
\hline Basidiomycota & Hyphoderma praetermissum & White rot & & yes & 0.02 & 0.02 \\
\hline Basidiomycota & Phlebia livida & White rot & no & yes & & 0.01 \\
\hline Basidiomycota & Phlebia subserialis & White rot & no & yes & 0.01 & \\
\hline Basidiomycota & Botryobasidium subcoronatum & White rot & no & yes & & 0.01 \\
\hline Basidiomycota & Trichaptum fuscoviolaceum & White rot & no & yes & 0.01 & 0.01 \\
\hline Basidiomycota & Hyphodontia floccosa & White rot & no & yes & 0.01 & \\
\hline Basidiomycota & Phlebia tremellosa & White rot & no & yes & 0.01 & \\
\hline Basidiomycota & Botryobasidium subcoronatum & White rot & no & yes & & 0.01 \\
\hline Basidiomycota & Tyromyces chioneus & White rot & no & yes & & 0.01 \\
\hline Basidiomycota & Hypholoma fasciculare & White rot & no & yes & & 0.01 \\
\hline Basidiomycota & Hypochnicium subrigescens & & & & & 0.01 \\
\hline Basidiomycota & Hyphoderma obtusiforme & White rot & no & yes & & 0.01 \\
\hline Basidiomycota & Hyphoderma puberum & White rot & no & yes & & 0.01 \\
\hline Basidiomycota & Peniophorella pallida & & & & 0.04 & \\
\hline Basidiomycota & Botryobasidium sp & & & & 0.01 & 0.01 \\
\hline Basidiomycota & Dacrymyces sp 1233 & & & & 0.01 & \\
\hline Basidiomycota & Dacrymyces sp 2551 & & & & 0.08 & 0.03 \\
\hline Basidiomycota & Coniophora sp & & & & 0.01 & \\
\hline Basidiomycota & Unidentified & & & & & 0.02 \\
\hline
\end{tabular}




\section{Table 2 (on next page)}

Fungal species that were significantly differentially abundant in full-tree or tree-length harvesting treatments at Island Lake.

Differential abundance was quantified using DeSeq2 with an adjusted P-value of 0.05 or lower considered as significant association with a treatment. Negative values for log-fold change in abundance between treatments corresponds to an association with the full-tree treatment, and positive log-fold changes represent an association with the tree-length treatment. Information on the ecology, pathogenicity, and wood-decaying ability of fungi was obtained from literature sources (see Methods text for details). For ecology, pathogenicity, and wood-decaying ability, a blank cell indicates we were unable to find information for the species. 


\begin{tabular}{|c|c|c|c|c|c|c|c|}
\hline Denovo & Phylum & Species & Ecology & Pathogen & $\begin{array}{l}\text { Wood } \\
\text { decaying } \\
\text { fungi }\end{array}$ & $\begin{array}{l}\text { Log-fold } \\
\text { change in } \\
\text { abundance } \\
\text { between } \\
\text { treatments }\end{array}$ & $\begin{array}{l}\text { Adjusted } \\
\text { P-value }\end{array}$ \\
\hline \multicolumn{8}{|l|}{ Full-tree } \\
\hline OTU811 & Basidiomycota & Peniophorella pallida & White rot & no & yes & -5.14 & $<0.01$ \\
\hline OTU484 & Ascomycota & Tephromela sp & Lichen & no & & -3.54 & $<0.01$ \\
\hline OTU1451 & Ascomycota & Trichoderma citrinoviride & soil fungus & no & & -2.71 & $<0.01$ \\
\hline OTU2268 & Ascomycota & Rhizoscyphus ericae & Ectomycorrhiza & no & & -2.70 & $<0.01$ \\
\hline OTU1918 & Ascomycota & Scytalidium lignicola & & no & yes & -2.47 & $<0.01$ \\
\hline OTU2735 & Ascomycota & Leptodontidium elatius & Black yeast fungi & no & yes & -2.18 & $<0.01$ \\
\hline OTU959 & Ascomycota & Xylomelasma sp & & & & -2.21 & $<0.05$ \\
\hline OTU668 & Ascomycota & Mytilinidion mytilinellum & & no & no & -1.71 & $<0.05$ \\
\hline OTU905 & Ascomycota & Penicillium sp & & & & -1.69 & $<0.05$ \\
\hline OTU875 & Basidiomycota & Saitozyma sp & Yeast & no & yes & -1.64 & $<0.05$ \\
\hline OTU1019 & Basidiomycota & Serpula himantioides & Brown rot & yes & yes & -1.56 & $<0.05$ \\
\hline OTU729 & Ascomycota & Rhizoscyphus ericae & Ericoid mycorrhiza & & & -1.41 & $<0.05$ \\
\hline OTU2158 & Basidiomycota & Thelephora terrestris & Ectomycorrhiza & & & -1.39 & $<0.05$ \\
\hline OTU97 & Ascomycota & unidentified & & & & -1.35 & $<0.05$ \\
\hline \multicolumn{8}{|c|}{ Tree-length } \\
\hline OTU436 & Basidiomycota & Phlebia livida & White rot & no & yes & 3.68 & $<0.01$ \\
\hline OTU747 & Ascomycota & Unidentified & & & & 1.81 & $<0.01$ \\
\hline OTU2285 & Ascomycota & Cladophialophora chaetospira & Black yeast fungi & no & & 1.65 & $<0.01$ \\
\hline OTU672 & Basidiomycota & Russula sp & Ectomycorrhiza & & & 1.57 & $<0.05$ \\
\hline OTU2105 & Ascomycota & Capronia semiimmersa & & & yes & 1.43 & $<0.05$ \\
\hline
\end{tabular}

